University of Nebraska - Lincoln

DigitalCommons@University of Nebraska - Lincoln

Publications from USDA-ARS / UNL Faculty

U.S. Department of Agriculture: Agricultural

Research Service, Lincoln, Nebraska

2007

\title{
Evidence of varietal adaptation to organic farming systems
}

Kevin M. Murphy

Washington State University

Kimberly A. Garland-Campbell

USDA-ARS, kim.garland-campbell@usda.gov

Steven R. Lyon

Washington State University

Stephen S. Jones

Washington State University

Follow this and additional works at: https://digitalcommons.unl.edu/usdaarsfacpub

Part of the Agricultural Science Commons

Murphy, Kevin M.; Garland-Campbell, Kimberly A.; Lyon, Steven R.; and Jones, Stephen S., "Evidence of varietal adaptation to organic farming systems" (2007). Publications from USDA-ARS / UNL Faculty. 422. https://digitalcommons.unl.edu/usdaarsfacpub/422

This Article is brought to you for free and open access by the U.S. Department of Agriculture: Agricultural Research Service, Lincoln, Nebraska at DigitalCommons@University of Nebraska - Lincoln. It has been accepted for inclusion in Publications from USDA-ARS / UNL Faculty by an authorized administrator of DigitalCommons@University of Nebraska - Lincoln. 


\title{
Evidence of varietal adaptation to organic farming systems
}

\author{
Kevin M. Murphy ${ }^{\text {a }}$, Kimberly G. Campbell ${ }^{\mathrm{b}}$, Steven R. Lyon ${ }^{\mathrm{a}}$, Stephen S. Jones ${ }^{\mathrm{a}, *}$ \\ ${ }^{a}$ Department of Crop and Soil Sciences, Washington State University, 201 Johnson Hall, Pullman, WA 99164-6420, United States \\ b 379 Johnson Hall, USDA-ARS, Pullman, WA 99164-6420, United States
}

Received 13 November 2006; received in revised form 22 March 2007; accepted 26 March 2007

\begin{abstract}
Consumer demand regarding the impacts of conventional agriculture on the environment and human health have spurred the growth of organic farming systems; however, organic agriculture is often criticized as low-yielding and unable to produce enough food to supply the world's population. Using wheat as a model crop species, we show that poorly adapted cultivars are partially responsible for the lower yields often found in organic farming systems when compared with conventional farming systems. Our results demonstrate that the highest yielding soft white winter wheat genotypes in conventional systems are not the highest yielding genotypes in organic systems. An analysis of variance for yield among 35 genotypes between paired organic and conventional systems showed highly significant $(P<0.001)$ genotype $\times$ system interactions in four of five locations. Genotypic ranking analysis using Spearman's rank correlation coefficient $\left(R_{\mathrm{S}}\right)$ showed no correlation between genotypic rankings for yield in four of five locations; however, the ranks were correlated for test weight at all five locations. This indicates that increasing yield in organic systems through breeding will require direct selection within organic systems rather than indirect selection in conventional systems. Direct selection in organic systems produced yields $15 \%, 7 \%, 31 \%$ and 5\% higher than the yields resulting from indirect selection for locations $1-4$, respectively. With crop cultivars bred in and adapted to the unique conditions inherent in organic systems, organic agriculture will be better able to realize its full potential as a high-yielding alternative to conventional agriculture.
\end{abstract}

Published by Elsevier B.V.

Keywords: Plant breeding; Genotype $\times$ system interaction; Organic agriculture; Wheat; Indirect selection

\section{Introduction}

The major challenge of organic farming systems is to maintain high yields and excellent quality utilizing farming practices that have acceptable environmental impacts (Tilman et al., 2002). Organic farming has been shown to improve many different environmental and human components of the agroecosystem (Bulluck et al., 2002; Kramer et al., 2006; Reganold et al., 2001).

Despite the potential environmental benefits of organic farming, the question must be addressed of whether organic agricultural systems are capable of producing enough food to feed the world's population today and in 2050, when global population is projected to reach 9 billion and global grain demand is expected to double (Tilman et al., 2002). Organic agriculture has been criticized as low-yielding and less efficient than conventional agriculture in its use of land and resources

\footnotetext{
* Corresponding author. Tel:: +1 509335 4877; fax: +1 5093358674 . E-mail addresses: joness@wsu.edu, jones1@indiana.edu (S.S. Jones).
}

(Trewavas, 2004). The term 'conventional' is defined in this paper as high-input, chemical intensive agricultural systems.

Several yield trial comparisons between organic and conventional farming systems have shown significantly lower yields for organic systems (Ryan et al., 2004; Stanhill, 1990). Padel and Lampkin (1994) reported that crop yield comparisons depend on the crop in question, with $60 \%$ lower yields in California rice (Oryza sativa L.) and 50\% higher yields in Midwest oats (Avena spp.) for organic agriculture. Other studies of organic and/or alternative (low input/sustainable) systems report yields comparable to conventional systems in maize (Zea mays) (Pimentel et al., 2005), apples (Malus spp.) (Reganold et al., 2001), tomatoes (Lycopersicon lycopersicum) (Clark et al., 1999) and soybeans (Glycine max (L.) Merr.) (Pimentel et al., 2005; Smolik and Dobbs, 1991; Stanhill, 1990).

These studies describe current conditions in organic and conventional agriculture in a variety of crop species; however, they rely primarily on modern cultivars that have been selected by plant breeders under conventional systems that may not accurately represent the conditions present in organic farming 
systems. For this reason, these studies may be biased toward finding higher yields in a chemical intensive conventional agriculture.

Grain yield and test weight are considered the two most important traits in the selection of soft white wheat cultivars in the United States. Yield is an excellent general indicator of the important interactions of many different genetic and environmental factors and can be used as an appropriate measurement of genotypic response to system-specific conditions. Test weight affects the productivity, efficiency, and operating costs of flour milling and is a good overall quality characteristic for soft white wheat. Wheat grain with high-test weight will usually contain kernels that reduce milling costs and increase flour yields relative to wheat grain with low-test weight. All genotypes in this study are in the soft white market class. Soft white wheat is used to make flour for bakery products other than bread, such as cakes, crackers, cookies, pastries and muffins. Unlike bread, these end-use products do not require high levels of protein; therefore, soft white wheat cultivars are not fertilized with levels of nitrogen comparable to hard red wheat varieties.

We compared grain yield and test weight of 35 soft white winter wheat (Triticum aestivum L.) genotypes (advanced breeding lines) in two systems (certified organic and conventional) over 5 site/years (locations) in Washington State. The paired organic and conventional nurseries were located on adjacent fields or farms with similar soil types, microclimatic weather conditions and topography to minimize non-system specific variation. In the US, the current working hypothesis is that breeding and selection under conventional systems will also produce crop cultivars well adapted to organic systems. The alternative hypothesis, that the highest yielding cultivars with the best quality in conventional systems are not the highest yielding cultivars with the best quality in organic systems, would suggest the need for breeding and selection under organic conditions.

\section{Materials and methods}

\subsection{Experimental design}

Randomized complete block nurseries with four replicates of 35 advanced soft white winter wheat breeding lines $\left(\mathrm{F}_{7}-\mathrm{F}_{9}\right)$ were grown in paired organic and conventional systems in five locations (site/years) in Washington State. All 35 genotypes were selected from the $\mathrm{F}_{2}$ generation in conventionally managed fields and represent the most promising lines in the Washington State University winter wheat breeding program each year. Locations 1 and 2 were evaluated in 2002-2003 and locations 3-5 were evaluated in 2004-2005. Because genotypes are added and dropped from the advanced nursery each year, the genotypes were not consistent between years but were consistent within years. The organic and conventional nurseries were separated by buffer strips ( $7 \mathrm{~m}$ minimum), though otherwise located in similar microclimatic conditions with comparable soil properties. The conventional nurseries were treated according to standard agricultural practice, including the use of crop-protection chemicals and inorganic fertilizer. The organic nurseries were located on certified organic ground and treated according to the regulations set by the USDA National Organic Program. Genotypes were uniform for maturity date and entire plots were harvested on the same day for both systems in each location using a Hege plot combine. Grain yield was recorded as dry weight (g) per plot. Test weight was estimated as the dry weight $(\mathrm{g})$ per $400 \mathrm{ml}$ for each replicate.

Locations 1 (2002-2003) and 3 (2004-2005) represent two farms near St. Andrews in Douglas County, WA (latitude $47^{\circ} 47^{\prime} \mathrm{N}$, longitude $119^{\circ} 22^{\prime} \mathrm{W}$ ) on a Timentwa loam soil type with similar weather patterns and winter wheat/summer fallow cropping rotations. The annual precipitation in this region is approximately $300 \mathrm{~mm} /$ year. Seeding rate at locations 1 and 3 is approximately $55 \mathrm{~kg} / \mathrm{ha}$. The conventional nursery was fertilized with $46.0 \mathrm{~kg} / \mathrm{ha}$ of $\mathrm{N}$ and sprayed with $23.5 \mathrm{~g} / \mathrm{ha}$ Harmony Extra (Tribenuron methyl, Thifensulfuron methyl) and 0.5 1/ha Buctril (Bromoxynil) herbicide with a non-ionic surfactant. The organic nursery was fertilized with PerfectBlend $^{\circledR}$ organic fertilizer at the rate of $3.35 \mathrm{~kg} / \mathrm{ha}$ each of $\mathrm{N}, \mathrm{P}$ and $\mathrm{K}$ and drilled with the seed at planting. The organic farm in Douglas County has been certified since 2000. Plots consisted of four rows at $30 \mathrm{~cm}$ spacing, $2.5 \mathrm{~m}$ long and $1.25 \mathrm{~m}$ wide.

Locations 2 (2002-2003), 4 and 5 (2004-2005) are at the Spillman Agronomy Farm near Pullman in Whitman County, WA (latitude $46^{\circ} 73^{\prime} \mathrm{N}$, longitude $117^{\circ} 18^{\prime} \mathrm{W}$ ) on a Palouse silt loam soil, where annual precipitation is $>500 \mathrm{~mm} /$ year. Seeding rate at these locations was approximately $98 \mathrm{~kg} / \mathrm{ha}$. The organic fields at Spillman Farm have been certified organic since 2002. The conventional nursery was fertilized with $100.8 \mathrm{~kg} / \mathrm{ha}$ of $\mathrm{N}, 22.7 \mathrm{~kg} / \mathrm{ha}$ of phosphate and $17.0 \mathrm{~kg} / \mathrm{ha}$ of sulphur incorporated into the soil within a week of planting. Seed was treated with Raxil ${ }^{\circledR}$-Thiram fungicide (Tebuconazole, Thiram) and Gaucho ${ }^{\circledR} 480$ (Imidacloprid) insecticide before planting at all conventional locations. Weed control in these conventional nurseries was accomplished with one application of $140 \mathrm{~g}$ of Sencor (Metribuzin) and 1.2 1/ha of Bronate (Bromoxynil) and hand weeding throughout the growing season. The conventional system was managed as a 2-year winter wheat/summer fallow rotation. The organic nursery was fertilized with PerfectBlend ${ }^{\mathbb{R}}$ organic fertilizer at the rate of $6.05 \mathrm{~kg} / \mathrm{ha}$ each of $\mathrm{N}, \mathrm{P}$, and $\mathrm{K}$, placed with the seed at planting. The 2-year rotation in the organic systems was winter pea plowdown/winter wheat. The winter pea rotation provided supplemental nitrogen at approximately $40 \mathrm{~kg} / \mathrm{ha}$. No fungicidal or insecticidal seed treatments were used at the organic locations. Weeds were left in the field until the week before harvest. Plots in Whitman County consisted of seven rows at $18 \mathrm{~cm}$ spacing, $2.5 \mathrm{~m}$ long and $1.25 \mathrm{~m}$ wide.

\subsection{Statistical analysis}

Data were analyzed using analysis of variance software PROC GLM (SAS Institute, Cary, NC). Each location was analyzed as an independent experiment. Levene's test was used to test for homogeneity of variance and normality was checked using PROC Univariate (SAS Institute, Cary, NC). Fixed factors in the analysis of variance included system and location; 
genotype was analyzed as a random factor. All genotypes were selected from Washington State University winter wheat advanced breeding lines, and are considered to be a population representing the germplasm in that breeding program. Spearman's rank correlation coefficient $\left(R_{\mathrm{S}}\right)$ was calculated using the following equation:

$R_{\mathrm{S}}=\frac{1-6 \sum d^{2}}{n\left(n^{2}-1\right)}$

where $\sum d^{2}$ is the difference in rank change of each genotype squared and summed for all 35 genotypes and $n$ is the number of genotypes. Statistical significance was assessed at the 5\% probability level unless otherwise stated.

\section{Results}

\subsection{Yield}

Conventional systems yielded higher than organic systems at locations 1 and $3(P<0.001$, Table 1$)$. The yields in conventional systems were greater than in the organic systems by approximately $38 \%$ and $60 \%$ for locations 1 and 3, respectively. No differences between systems for yield were observed in locations 2, 4 and 5. Differences for yield among genotypes were found in each location and for both conventional and organic systems $(P<0.001)$. An analysis of variance showed genotype $\times$ system interactions for yield between systems in four of the five locations (Table 1).

\subsection{Test weight}

Conventional systems had significantly higher test weights at locations 1 and 3, while the organic system had significantly

Table 1

Differences in yield between organic and conventional systems

\begin{tabular}{|c|c|c|c|c|c|}
\hline Location & System & Yield & $N$ & $\mathrm{G} \times \mathrm{S}$ (d.f.) & $R_{\mathrm{S}}$ yield \\
\hline 1 & $\begin{array}{l}\text { Organic } \\
\text { Conventional }\end{array}$ & $\begin{array}{c}956 \\
1530^{* * * *}\end{array}$ & $\begin{array}{l}140 \\
140\end{array}$ & $<0.0001$ & -0.03 \\
\hline 2 & $\begin{array}{l}\text { Organic } \\
\text { Conventional }\end{array}$ & $\begin{array}{l}2028 \\
2400\end{array}$ & $\begin{array}{l}140 \\
140\end{array}$ & $0.1435(34)$ & 0.26 \\
\hline 3 & $\begin{array}{l}\text { Organic } \\
\text { Conventional }\end{array}$ & $\begin{array}{l}1058 \\
2668^{* * * *}\end{array}$ & $\begin{array}{l}140 \\
140\end{array}$ & $0.0092(34)$ & 0.08 \\
\hline 4 & $\begin{array}{l}\text { Organic } \\
\text { Conventional }\end{array}$ & $\begin{array}{l}2105 \\
2068\end{array}$ & $\begin{array}{l}130 \\
140\end{array}$ & $0.0007(34)$ & 0.11 \\
\hline 5 & $\begin{array}{l}\text { Organic } \\
\text { Conventional }\end{array}$ & $\begin{array}{l}1850 \\
1952\end{array}$ & $\begin{array}{l}130 \\
140\end{array}$ & $<0.0001(34)$ & $0.79^{* *}$ \\
\hline Mean & $\begin{array}{l}\text { Organic } \\
\text { Conventional }\end{array}$ & $\begin{array}{l}1599 \\
2124^{* * * *}\end{array}$ & $\begin{array}{l}680 \\
700\end{array}$ & - & - \\
\hline
\end{tabular}

Mean yield $\left(\mathrm{g} / 3.5 \mathrm{~m}^{2}\right)$, number of observations $(N), P$-value for genotype by system interaction $(\mathrm{G} \times \mathrm{S})$ with degrees of freedom (d.f.), Spearman's rank correlation coefficient for yield $\left(R_{\mathrm{S}}\right.$ yield) measured in paired organic/conventional experiments with 35 soft white winter wheat genotypes at each of five locations.

*** $P<0.01$.

*** $P<0.001$.
Table 2

Differences in test weight between organic and conventional systems

\begin{tabular}{llllll}
\hline Location & System & TW & $N$ & $\mathrm{G} \times \mathrm{S}(\mathrm{df})$ & $R_{\mathrm{S}} \mathrm{TW}$ \\
\hline 1 & Organic & 422 & 140 & $0.0004(34)$ & $0.60^{*}$ \\
& Conventional & $441^{* * *}$ & 140 & & \\
2 & Organic & 425 & 140 & $0.264(34)$ & $0.75^{* *}$ \\
& Conventional & 427 & 140 & & \\
3 & Organic & 424 & 140 & $<0.0001(34)$ & $0.56^{*}$ \\
& Conventional & $435^{* * *}$ & 140 & & \\
4 & Organic & 425 & 130 & $0.0007(34)$ & $0.85^{* *}$ \\
& Conventional & 422 & 140 & & \\
5 & Organic & $428^{*}$ & 130 & $<0.0001(34)$ & $0.61^{*}$ \\
& Conventional & 420 & 140 & & - \\
\multirow{2}{*}{ Mean } & Organic & 425 & 680 & - & \\
& Conventional & 429 & 700 & &
\end{tabular}

Mean test weight $(\mathrm{TW})(\mathrm{g} / 400 \mathrm{ml})$, number of observations $(N), P$-value for genotype by system interaction $(\mathrm{G} \times \mathrm{S})$ with degrees of freedom (d.f.), Spearman's rank correlation coefficient for test weight $\left(R_{\mathrm{S}} \mathrm{TW}\right)$ measured in paired organic/conventional experiments with 35 soft white winter wheat genotypes at each of five locations.

* $P<0.05$.

** $P<0.01$.

**** $P<0.001$

higher test weight at location 5 (Table 2). There was no difference in test weight between organic and conventional systems at locations 2 and 4 . Test weights in the conventional systems were greater than in the organic systems by approximately $4 \%$ and $2.5 \%$ for locations 1 and 3 , respectively. Test weights in the organic systems were greater than in the conventional systems by approximately $2 \%$ for location 5 . Differences for test weight among genotypes were found in each location $(P<0.001)$. Genotype $\times$ system interactions were found for test weight between systems in four of five locations $(P<0.001$, Table 2$)$.

\subsection{Rank correlations}

Spearman's rank correlation coefficient $\left(R_{\mathrm{S}}\right)$ was used to determine the level of rank correlation between systems of all 35 genotypes. There was no positive genotypic rank correlations for yield among systems in four locations $\left(R_{\mathrm{S}}=-0.03\right.$, $0.26,0.08$ and 0.11 , respectively, for locations $1-4)$. Only Location 5 showed a rank correlation for yield $\left(R_{\mathrm{S}}=0.79\right.$, $P<0.05)$. All locations showed a positive rank correlation for test weight, ranging from $R_{\mathrm{S}}=0.56$ to $R_{\mathrm{S}}=0.85$ (Table 2 ).

\subsection{Direct versus indirect selection}

When organic systems were the target environment, direct selection in organic systems produced higher yields in locations 1-4 than indirect selection in conventional systems (Fig. 2). When conventional systems were the target environment, direct selection in conventional systems produced higher yields than indirect selection in organic systems at locations 2 and 3 . There was no difference between direct and indirect selection for location 5 . 


\section{Discussion}

\subsection{Yield}

The higher yields in conventional systems in locations 1 and 3 are most likely due to extremely low levels of nitrogen inputs in the organic systems. The cropping rotation in this region is predominantly winter wheat/summer fallow and the low amount of rainfall generally prevents the inclusion of a nitrogen fixing legume in the cropping rotation because there is not enough soil moisture left after the legume harvest to germinate winter wheat. No differences for yield were observed in locations 2, 4 and 5, where a green manure winter pea plowdown is included in the cropping rotation for organic systems. This indicates the importance of obtaining an economical source of nitrogen in cereal based cropping systems coupled with using cultivars with high nitrogen use efficiency. Without cultivars adapted to low levels of nitrogen inputs, organic wheat farmers in low rainfall regions $(<300 \mathrm{~mm} /$ year $)$ will likely be unable to achieve yields comparable to conventional farmers.

\subsection{Genotype $\times$ system interaction}

Analysis of variance estimation of genotype $\times$ system interaction has been used to indicate a need for selection of crop cultivars within specific farming systems in order to optimize yield within these cropping systems. Several studies have shown that no differences exists among cultivar performance in different production systems, including tillage systems (Carr et al., 2003; Rao and Dao, 1994; Weisz and Bowman, 1999), intercropping and double-cropping (Panter and Allen, 1989; Santalla et al., 2001) and nitrogen input level systems (Hasegawa, 2003). By contrast, several studies have shown differences among cultivar performance when evaluated in different agronomic systems, including intercropping (O'Leary and Smith, 1999), low input environments (Atlin and Frey, 1990; Brancourt-Hulmel et al., 2005; Brun and Dudley, 1989; Ceccarelli, 1994; Muruli and Paulsen, 1981), drought stressed (Arboleda-Rivera and Compton, 1974) and salinity stressed environments (Kelman and Qualset, 1991). These studies indicate that separate breeding programs are necessary for those cropping systems that differ from conventional systems.

We used analysis of variance to test for significant genotype $\times$ system interactions between organic and conventional cropping systems. Tables 1 and 2, respectively, show genotype by system interactions for yield and test weight in four of the five locations. These results provide evidence for the need to select for yield and test weight within organic systems. However, this statistical test may not provide enough evidence to determine if a separate breeding program is warranted. Interactions can occur without significant genotypic changes in rank. It is therefore possible to have a genotype $\times$ system interaction; however, the highest yielding cultivars in one system might still be the highest yielding cultivars in another system. In this scenario, the development of a separate breeding program is unnecessary. Rather, selection for specific traits suitable to organic farmers could occur within an existing 'conventional' breeding program.

\subsection{Rank correlation}

To address this possibility, we estimated rank correlations between systems for yield and test weight. The lack of genotypic rank correlations for yield in four of the five locations indicates that the rankings of high yielding genotypes in conventional systems are unreliable predictors of the rankings of high yielding genotypes in organic systems. Only in location 5 is the ranking of genotypes in the conventional system a reliable predictor of the ranking of genotypes in the organic system. The positive rank correlation for yield in location 5 is consistent with the relatively minor changes in ranks (compared with locations 1-4) found in the top five varieties shown in Fig. 1. Fig. 1 shows that the majority of the top five ranked genotypes for yield in conventional systems are ranked much lower in organic systems.

The reverse is also true. Several genotypes are ranked high in both systems, indicating broad non-system specific adaptation and the potential for selection of varieties capable of high yields across systems. These broadly adapted genotypes are the exception rather than the rule, however, and these results indicate that yield evaluations must be done in both systems to identify these relatively few broadly adapted genotypes. Because there were no correlations in rank among the 35 genotypes for yield in four of the five locations, we can conclude that most of the best varieties in organic systems would be dropped from the conventional breeding program during selection for yield.

The positive rank correlations for test weight between systems suggest that selection for high quality soft white wheat cultivars can occur in either system. However, if improving test weight for organic systems in a high yielding genetic background is the primary objective of a breeding program, a separate organic breeding program will be necessary.

\subsection{Direct versus indirect selection}

Plotting ranks could accentuate the changes more than is actually occurring if there are no yield differences between

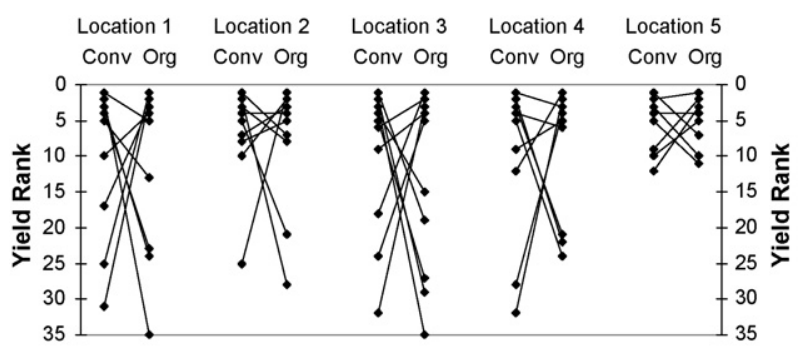

Fig. 1. Genotypic change in rank between organic and conventional wheat nurseries. The top five ranking genotypes for yield in both organic and conventional systems were compared at each location. Genotypes are ranked from 1 = highest yield to $35=$ lowest yield . 


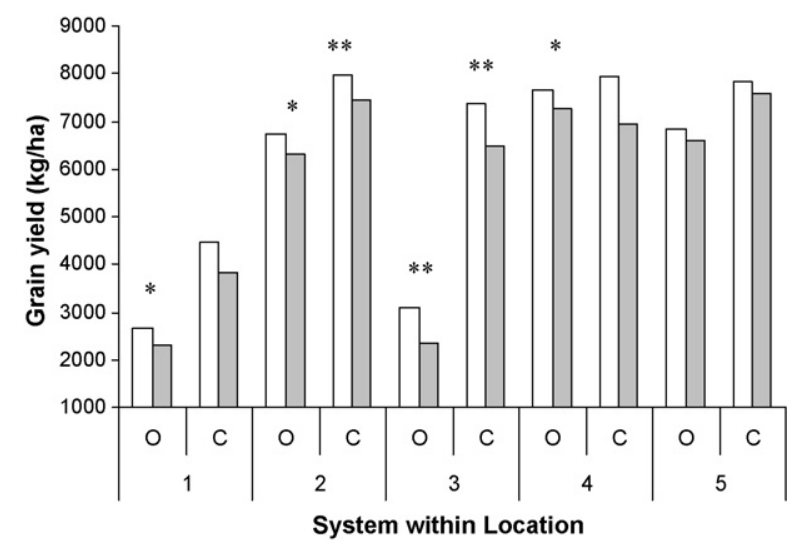

Fig. 2. Direct selection vs. indirect selection in organic (O) and conventional (C) systems. The white bar is the mean yield of the top five lines in each system (direct selection). The shaded bar represents the mean yield of the top five lines from the opposing system (indirect selection). ${ }^{*} P<0.05 ;{ }^{* *} P<0.01$.

direct and indirect selection. Indirect selection in this case refers to selection for yield in one system when the target environment is the other system. Fig. 2 illustrates the differences in yield among the top five genotypes when subject to direct and indirect selection in both systems. In six of the 10 environments, direct selection resulted in higher yields than indirect selection. Four of these environments were in the organic system and two were in the conventional system. There was no difference for either system in location 5 , which is consistent with the significant $R_{\mathrm{S}}$ estimates at this location. Direct selection in organic systems produced yields $15 \%, 7 \%$, $31 \%$ and $5 \%$ higher than the yields resulting from indirect selection for locations 1-4, respectively. Direct selection was particularly effective in the low nitrogen, low rainfall locations.

\section{Implications for organic crop breeding}

Due to the increasing consumer demand and subsequent growth of organic products at approximately $20 \%$ per year, organic cropping systems would benefit from increased research from plant breeders. Today, many organic farming systems are in place but operating with the handicap of using cultivars better adapted to high-input, chemical intensive farming systems. Our results, including significant genotype $\times$ system interactions, significant genotypic changes in ranking, and yield gains resulting from direct selection in organic systems, indicate the importance of utilizing a separate breeding program when selecting for high yielding organic wheat cultivars with good quality characteristics.

Breeding programs dedicated to organic agriculture would focus on traits including improved nitrogen and nutrient-use efficiency, adaptation to soil microbes, improved competitiveness against weeds and resistance to insects and diseases currently controlled with chemical pesticides. With the incorporation of these traits into high yielding cultivars, organic agriculture will be better equipped to realize its full potential as a viable alternative to conventional agriculture.

\section{Acknowledgements}

Authors would like to acknowledge M. Evans for statistical assistance and thank F. Muehlbauer, K. McPhee, S. Ceccarelli, P. Carr, J. Reganold and two anonymous reviewers for valuable comments on the manuscript. This work was supported by grants from the Center for Sustaining Agriculture and Natural Resources at Washington State University, the Organic Farming Research Foundation and the USDA Integrated Organic Program (Proposal Number: 2006-02057). The authors declare no competing financial interests.

\section{References}

Arboleda-Rivera, F., Compton, W.A., 1974. Differential response of maize (Zea mays L.) to mass selection in diverse selection environments. Theor. Appl. Genet. 44, 44-81.

Atlin, G.N., Frey, K.J., 1990. Selecting oat lines for yield in low-productivity environments. Crop Sci. 30, 556-561.

Brancourt-Hulmel, M., Heumez, E., Pluchard, P., Beghin, D., Depatureaux, C., Giraud, A., Le Gouis, J., 2005. Indirect versus direct selection of winter wheat for low-input or high-input levels. Crop Sci. 45, 14271431.

Brun, E.L., Dudley, J.W., 1989. Nitrogen response in USA and Argentina of corn populations with different proportions of flint and dent germplasm. Crop Sci. 29, 565-569.

Bulluck III, L.R., Brosius, M., Evanylo, G.K., Ristaino, J.B., 2002. Organic and synthetic fertility amendments influence soil microbial, physical and chemical properties on organic and conventional farms. Appl. Soil Ecol. 19, 147-160.

Carr, P.M., Horsley, R.D., Poland, W.W., 2003. Tillage and seeding rate effects on wheat cultivars. I. Grain production. Crop Sci. 43, 202-209.

Ceccarelli, S., 1994. Specific adaptation and breeding for marginal conditions. Euphytica 77, 205-219.

Clark, M.S., Horwath, W.R., Shennan, C., Scow, K.M., Lantni, W.T., Ferris, H., 1999. Nitrogen, weeds and water as yield-limiting factors in conventional, low-input, and organic tomato systems. Agric. Ecosyst. Environ. 73, 257270.

Hasegawa, H., 2003. Crop ecology, management \& quality: high-yielding rice cultivars perform best even at reduced nitrogen fertilizer rate. Crop Sci. 43, 921-926.

Kelman, W.M., Qualset, C.O., 1991. Breeding for salinity-stressed environments: recombinant inbred wheat lines under saline irrigation. Crop Sci. 31, 1436-1442.

Kramer, S.B., Reganold, J.P., Glover, J.D., Bohannan, B.J.M., Mooney, H.A., 2006. Reduced nitrate leaching and enhanced denitrifier activity and efficiency in organically fertilized soils. Proc. Natl. Acad. Sci. U.S.A. 103, 4522-4527.

Muruli, B.I., Paulsen, G.M., 1981. Improvement of nitrogen use efficiency and its relationship to other traits in maize. Maydica 26, 63-73.

O’Leary, N., Smith, M.E., 1999. Breeding corn for adaptation to two diverse intercropping companions. Am. J. Alternative Agric. 14, 158-164.

Padel, S., Lampkin, N.H., 1994. Conversion to organic farming: an overview. In: Lampkin, N.H., Padel, S. (Eds.), The Economics of Organic Farming. CAB, Wallingford, UK, pp. 295-313.

Panter, D.M., Allen, F.L., 1989. Simulated selection for superior yielding soybean lines in conventional vs. double-crop nursery environments. Crop Sci. 29, 1341-1346.

Pimentel, D., Hepperly, P., Hanson, J., Douds, D., Seidel, R., 2005. Environmental, energetic and economic comparisons of organic and conventional farming systems. Bioscience 55, 573-582.

Rao, S.C., Dao, T.H., 1994. Straw quality of 10 wheat cultivars under conventional and no-till systems. Agron. J. 86, 833-837.

Reganold, J.P., Glover, J.D., Andrews, P.K., Hinman, H.R., 2001. Sustainability of three apple production systems. Nature 410, 926-930. 
Ryan, M.H., Derrick, J.W., Dann, P.R., 2004. Grain mineral concentrations and yield of wheat grown under organic and conventional management. J. Sci. Food Agric. 84, 207-216.

Santalla, M., Rodino, A.P., Casquero, P.A., Ron, A.M.d., 2001. Interactions of bush bean intercropped with field and sweet maize. Eur. J. Agron. 15, 185-196.

Smolik, J.D., Dobbs, T.L., 1991. Crop yields and economic returns accompanying the transition to alternative farming systems. J. Prod. Agric. 4, 153-161.

Stanhill, G., 1990. The comparative productivity of organic agriculture. Agric. Ecosyst. Environ. 30, 1-26.
Tilman, D., Cassman, K.G., Matson, P.A., Naylor, R., Polasky, S., 2002. Agricultural sustainability and intensive production practices. Nature 418, 671-677.

Trewavas, A., 2004. A critical assessment of organic farming-andfood assertions with particular respect to the UK and the potential environmental benefits of no-till agriculture. Crop Prot. 23, 757781.

Weisz, R., Bowman, D.T., 1999. Influence of tillage system on soft red winter wheat cultivar selection. J. Prod. Agric. 12, 415-418. 